\title{
Partial characterization of genes from the embryonic axis of Melanoxylon brauna Schott. (Leguminosae-Caesalpinioideae) $\operatorname{seeds}^{1}$
}

\author{
Mirian de Sousa Silva ${ }^{2 *}$, Sérgio Hermínio Brommonschenkel ${ }^{3}$, \\ José Márcio Rocha Faria ${ }^{4}$, Eduardo Euclydes de Lima e Borges ${ }^{2}$
}

\begin{abstract}
The objective of this study was to partially characterize some genes involved in the desiccation tolerance of the embryonic axis of Melanoxylon brauna seeds subjected, or not, to oven fastdrying. Seeds were initially dried rapidly in an oven at $40^{\circ} \mathrm{C}, 50^{\circ} \mathrm{C}, 60^{\circ} \mathrm{C}, 70^{\circ} \mathrm{C}$, and $80^{\circ} \mathrm{C}$, for 24,48 and $72 \mathrm{~h}$ and then subjected to germination tests and moisture content determination. Degenerate primers were designed for 19 genes. The CDNA was used as a template for PCR amplifications using the degenerate primers, and the PCR products obtained were purified, cloned and sequenced. The seeds showed a gradual reduction in percent germination with increasing temperature and drying time. Nucleotide sequences of the cloned fragments related to genes CAT1, SPS1, Abi5, Transk and PM25 were obtained. The similarity analysis with the sequences deposited in databases revealed similarities with genes CAT1, SPS1, Transk and PM25 from other plant species. The nucleotide sequences obtained from the respective genes will be used for designing specific primers for gene expression analyses during seed germination in order to understand the causes for loss of physiological quality of Melanoxylon brauna seeds.
\end{abstract}

Index terms: water, stress, drying, sequencing.

\section{Caracterização parcial de genes do eixo embrionário de sementes de Melanoxylon brauna Schott. (Leguminosae-Caesalpinioideae)}

\begin{abstract}
RESUMO - O presente trabalho objetivou caracterizar parcialmente os genes envolvidos com a tolerância à dessecação do eixo embrionário de sementes de Melanoxylon brauna submetidas ou não à secagem rápida. As sementes foram submetidas à secagem rápida em estufa nas temperaturas de $40{ }^{\circ} \mathrm{C}, 50{ }^{\circ} \mathrm{C}, 60{ }^{\circ} \mathrm{C}, 70{ }^{\circ} \mathrm{C}$ e $80{ }^{\circ} \mathrm{C}$, nos tempos de 24,48 e $72 \mathrm{~h}$ e, em seguida, submetidas ao teste de germinação e determinação do grau de umidade. Foram utilizados primers degenerados para 19 genes. Os produtos de PCR obtidos foram purificados, clonados no vetor pGEM-T Easy e sequenciados. As sementes apresentaram redução gradativa na porcentagem de germinação com o aumento da temperatura e tempo de secagem. Foram obtidas as sequências dos fragmentos clonados referentes aos genes $C A T 1, S P S 1, A B I 5$, Transk e PM25. A comparação das sequências obtidas com sequências depositadas em bancos de dados revelou similaridade com os genes CAT1, SPS1, Transk e $P M 25$ de outras espécies. As sequências de nucleotídeos obtidas dos respectivos genes servirão para a confecção de oligonucleotídeos específicos para posteriores estudos de expressão gênica durante a germinação de sementes de $M$. brauna submetidas à secagem, visando entender as causas da perda de qualidade fisiológica dessas sementes.
\end{abstract}

Termos para indexação: água, secagem, sequenciamento, estresse.

\footnotetext{
${ }^{1}$ Submitted on 01/12/2010. Accepted for publiction on 08/29/2011.

${ }^{2}$ Departamento de Engenharia Florestal, Universidade Federal de Viçosa, 36570-000, Viçosa, MG, Brasil.

${ }^{3}$ Departamento de Fitopalogia, Universidade Federal de Viçosa, 36570-000, Viçosa, MG, Brasil.
}

${ }^{4}$ Departmento de Ciência Florestal, Universidade Federal de Lavras, 372000-000, Lavras, MG, Brasil.

*Corresponding author $<$ mirianfloresta@gmail.com> 


\section{Introduction}

Belonging to the family Leguminosae-Caesalpinioideae, the wild tree Melanoxylon brauna (known in Brazil as "braúna", its common name) is native of Brazil, occurring mainly in the Atlantic Forests of south regions of Bahia and states of São Paulo and Minas Gerais. Nowadays, According to the Instituto Brasileiro do Meio Ambiente e dos Recursos Naturais Renováveis - IBAMA (Brazilian Institute of Environment and Renewable Natural Resources), Decree number 37/92, the species is included in the Official List of Endangered Flora, in the category "vulnerable" (IBAMA, 2009).

Deficiencies in the knowledge on the ideal conditions for drying seeds of native forestal species have been a hindrance to success of germplasm banks, since not all seeds possess the same behavior (Davide et al., 2003). Thus, studies on the drying process become necessary because freshly harvested seeds generally have inadequate moisture content for safe storage (Villela and Peres, 2004).

Therefore, the determination of the adequate drying temperature as well as the exposition time to temperature is essential to avoid damages and the consequent loss of seeds quality, independently of the tolerance to desiccation.

The genes associated to the desiccation tolerance, especially those involved in metabolic changes (Leprince et al., 2000; Walters et al., 2002b), protection against oxidation (Pukacka and Ratajczak, 2005), and other supposed protectant molecules have shown particular expression pattern during desiccation. The gain of desiccation tolerance of orthodox seeds during their development has been correlated to different expression of genes such as $A B I 3, A B I 5, L E C l$ (Jones et al., 1997; Koornneef et al., 1984; Parcy et al., 1994; Harada, 2001), among others. The genes LEC (Leafy cotyledon) are defined by mutations in three loci in Arabidopsis, LEC1, LEC2 and FUSCA3 (FUS3) and are mainly involved on the embryo development (Harada, 2001). The gene $A B I 3$ (abscisic acid insensitive), however, is expressed specifically in the seed, being one of the most studied genes in relation to seed development (Parcy et al., 1994).

The genes $C A T$ (catalase) are considered antioxidants, being members of a small multi-genic family that includes the genes CAT1, CAT2 and CAT3 in Arabidopsis. Evidences suggest that in Arabidopsis the catalase expression and activity are always correlated to stresses (Williamson; Scandalios, 1992; Orendi et al., 2001; Verslues et al., 2007; Xing et al., 2007). The genes PER1 (1-CyS peroxiredoxin, PKABA1 (Abscisic acid induced Kinase) and SHSP (small heat-shock protein) are correlated to stress and also to desiccation tolerance in orthodox seeds
(Delseny et al., 2001; Aalen, 1999; Anderberg and WalkerSimmons, 1992; Wehmeyer and Vierling, 2000). The sHPS (small heat-shock proteins) synthesis, whose main function is to protect the cells during desiccation and rehydration (Coca et al., 1994; Alamillo et al., 1995), occurs as a response to high temperature conditions and its expression happens at specific plant developmental stages (Wehmeyer and Vierling, 2000). Several studies report that in plants the sHPS are divided into five genic families, being those based on the DNA sequence, immunological reactivity and intracellular localization (Waters et al., 1996).

The activation of sucrose phosphate sintase, a regulator enzyme in the assimilation and distribution of carbon in plants, works as a facilitator in the sucrose formation for the osmoregulation in the conversion of starch or lipid into sucrose during seeds germination (Huber and Huber, 1996). The sucrose synthesis in the leaves and seeds of desiccation tolerant higher plants, when stressed, occurs with the increase of specific sugars correlated to desiccation tolerance (Koster and Leopold, 1988; Crowe et al., 1984).

The transketolases act in the reduction and oxidation of the pentose phosphate pathway, being responsible for the intermediary synthesis of phosphate sugar, which can be utilized in the carbohydrates metabolism, nucleic acids and amino-acids biosynthesis reactions (Racker, 1961). According to Bernacchia et al. (1995), the differential expression of genic family during the rehydration phase in Craterostigma plantagineum plants suggested the hypothesis that the transketolases are able to act in the sugars conversion, the main phenomenon in the rehydration process.

The present research work aimed at partially characterizing the presence of some genes involved in desiccation tolerance of the embryonic axis of Melanoxylon brauna seeds.

\section{Material and Methods}

The Melanoxylon brauna seeds were collected from pods of four different mother-trees in the municipality of Leopoldina, State of Minas Gerais, Southeast Brazil. The pods were collected in September 2008, and after drying at room temperature for complete dehiscence, the seeds were manually selected eliminating the immature, deteriorated or damaged ones, being then placed into polyethylene bags $(0.65$ $\mathrm{mm}$ thickness) and stored into cardboard containers in a cold chamber $\left(5^{\circ} \mathrm{C}\right.$ temperature and $\left.60 \% \mathrm{RH}\right)$ for two months.

Moisture content determination: the procedure was performed by using the oven drying method, at $105^{\circ} \mathrm{C} \pm$ 
$3{ }^{\circ} \mathrm{C}$, for $24 \mathrm{~h}$ (Brasil, 2009), with three replications of 20 seeds each.

Oven drying: seeds were randomly remove from the original seed lot and subjected to drying in an oven of circulation and renewal of air, at temperatures of $40^{\circ} \mathrm{C}$, $50{ }^{\circ} \mathrm{C}, 60{ }^{\circ} \mathrm{C}, 70{ }^{\circ} \mathrm{C}$, and $80{ }^{\circ} \mathrm{C}$ for 24,48 and $72 \mathrm{~h}$, and then submitted to germination test.

Germination test: the seeds were previously treated with the fungicide Captan $(7 \% \mathrm{v} / \mathrm{v})$ and distributed into petri dishes containing two sheets of filter paper moisturized with $4 \mathrm{~mL}$ of $\mathrm{H}_{2} \mathrm{O}$, and then placed into a germination chamber at $25{ }^{\circ} \mathrm{C}$ temperature and constant light. The counting of germinated seeds was daily performed, considering germinated the seed presenting rootlet protrusion. Five replications of 20 seeds each were used.

Degenerated primers: the sequences of the 19 primers were provided by the forestal seeds research group of the Federal University of Lavras (Table 1). The primers were designed with the aid of the software GeneFisher (http:/ bibiserv.techfak.unibiefeled.de/genfisher2/submission.html) from sequences available in the GenBank/NCBI, National Center for Biotechnology Information, for Glycine max, Medicago sativa, Medicago truncatula, Mimosa pudica, Populus trichocarpa, and Zea mays, among other species.

Table 1. Genes selected for designing the degenerated primers.

\begin{tabular}{lll}
\hline Gene acronym & \multicolumn{1}{c}{ Gene name } & \multicolumn{1}{c}{ Function } \\
\hline ABI3 & Abscisic acid insensitive 3 & Development \\
ABI5 & Abscisic acid insensitive 5 & Development \\
Ald. Dehyd & Aldehyde dehydrogenase & Maturation \\
BADH & Betaine aldehyde dehydrogenase & Osmotic stress \\
CAT1 & Catalase 1 & Antioxidant \\
CSD2 & Cu/Zn superoxide dismutase & Antioxidant \\
ELIP & Early light induced protein & Photo-protectant \\
EM6 & Early methionine 6 & Tolerance to desiccation \\
$(M n)$ SOD & (Mn) superoxide dismutase & Tolerance to desiccation \\
LEC1 & Leafy cotyledon1 & Development \\
PER1 & 1-Cys peroxiredoxin & Tolerance to desiccation \\
$P K A B A$ & Abscisic acid induced Kinase & Tolerance to desiccation \\
$P M 25$ & Maturation protein & Maturation \\
Prx & Peroxiredoxins & Tolerance to desiccation \\
RD28 & Responsive to desiccation & Osmotic stress \\
SC514 & Lipoxygenase & Antioxidant \\
SHSP & Small heat-shock protein & Tolerance to desiccation \\
SPS1 & Sucrose phosphate syntase & Tolerance to desiccation \\
Transk & Transketolase & Tolerance to desiccation \\
\hline
\end{tabular}

Total RNA extraction: from each sample, the total RNA was extracted from $100 \mathrm{mg}$ of axis embryos according to PureLink ${ }^{\circledR}$ Plant RNA (Invitrogen) protocol. The total RNA was led to a re-suspension in $30 \mu \mathrm{L}$ of water free of RNA, stored at $70^{\circ} \mathrm{C}$ and then quantified with the aid of a Nanodrop (Spectrophotometer ND 1000) and its integrity was evaluated on agarose gel containing $1.2 \%$ formaldehyde (FA) $(1.2 \mathrm{~g}$ agarose, $10 \mathrm{~mL}$ of 10X FA buffer gel, $100 \mathrm{~mL} \mathrm{H}_{2} \mathrm{O}$ free of RNA, $9 \mu \mathrm{L}$ formaldehyde, and $2 \mu \mathrm{L}$ of ethidium bromide).
Synthesis of cDNA: the cDNA synthesis was accomplished by using the kit Super Script First-Strand Synthesis System for RT-PCR (Invitrogen) starting from $1 \mu \mathrm{g}$ of total RNA, according to manufacturer instructions.

Validation of degenerated primers: to verify the amplification specificity, the genomic DNA extracted from Arabidopsis thaliana leaves was used for the polymerase chain reaction (PCR). For this, $1 \mu \mathrm{L}$ DNA 
(15 ng), $2 \mu \mathrm{L}$ PCR reaction buffer (10X), $0.5 \mu \mathrm{L}$ primer reverse $(10 \mu \mathrm{M}), 0.5 \mu \mathrm{L}$ primer forward $(10 \mu \mathrm{M})$, $0.6 \mu \mathrm{L}$ dNTP $(2.5 \mathrm{mM}), 0.9 \mu \mathrm{L}$ Taq polymerase, and $14.5 \mu \mathrm{L}$ ultra-pure $\mathrm{H}_{2} \mathrm{O}$ were used. The reaction was scheduled for $94{ }^{\circ} \mathrm{C}$ during $2 \mathrm{~min}$., with cycles of $94{ }^{\circ} \mathrm{C}$ per sec., for DNA denaturation; $50{ }^{\circ} \mathrm{C}$ for $2 \mathrm{~min}$., for annealing the primers; and $72{ }^{\circ} \mathrm{C}$ for $1 \mathrm{~h}$ and $30 \mathrm{~min}$., for primers extension by Taq polymerase; being these cycles repeated 40 times and at $72{ }^{\circ} \mathrm{C}$ for $5 \mathrm{~min}$. In each groove of the $1 \%$ agarose gel $(1.0 \mathrm{~g}$ agarose, and $100 \mathrm{~mL}$ of TAE buffer) $20 \mu \mathrm{L}$ of the reaction was applied and the gel was then submitted to electrophoresis for 20 min., 70 at V. After the electrophoresis running, $2 \mu \mathrm{L}$ of ethidium bromide were added under agitation, for 20 min. The amplified fragments were visualized under UV light and the identification of the amplifications of interest was performed by comparing the product of PCR with the molecular weight marker.

Polymerase chain reaction with cDNA of the embryonic axis of Melanoxylon brauna: the degenerated oligonucleotides for the selected genes CAT1, PM25, SPS1, Transk, ABI5, PER1, RD28, SHSP, LEC1 and ABI3 presenting positive amplification with the utilization of Arabidopsis thaliana DNA were selected for amplification starting from the cDNA. For the reaction, $2 \mu \mathrm{L}$ of cDNA, $2 \mu \mathrm{L}$ of PCR reaction buffer (10X), $0.5 \mu \mathrm{L}$ of primer reverse $(100 \mu \mathrm{M}), 0.5 \mu \mathrm{L}$ of primer forward $(10 \mu \mathrm{M}), 0.6 \mu \mathrm{L}$ of dNTP (2.5 mM), $0.9 \mu \mathrm{L}$ of Taq polymerase enzyme, and $13.5 \mu \mathrm{L}$ of ultrapure $\mathrm{H}_{2} \mathrm{O}$ were used. The reaction was programmed for $94{ }^{\circ} \mathrm{C}$ during $2 \mathrm{~min}$, with cycles of $94{ }^{\circ} \mathrm{C}$ for $30 \mathrm{sec}$. for DNA denaturation; $52{ }^{\circ} \mathrm{C}$ for $30 \mathrm{sec}$. for annealing the primers; and $72{ }^{\circ} \mathrm{C}$ for $1 \mathrm{~min}$. for primers extension by Taq polymerase; being these cycles repeated 40 times and at $72{ }^{\circ} \mathrm{C}$ for $5 \mathrm{~min}$. In each groove of the $1 \%$ of agarose gel, $10 \mu \mathrm{L}$ of the reaction were applied. The proceeding procedures were the same previously described.

Cloning of the amplified segments starting from the cDNA: the product of the amplified sequences of the genes previously cited was cloned with the aid of the vector pGEM ${ }^{\text {TM}}-$ TEasy (Promega, USA), according to manufacturer instructions. In $50 \mu \mathrm{L}$ of component cells $\left(\mathrm{TOPO}^{\circledR}\right.$ Shotgun Subcloning (Invitrogen), $4 \mu \mathrm{L}$ of the linking reaction was added, incubated for $30 \mathrm{~min}$. dipped in ice and then submitted to thermal shock at $42^{\circ} \mathrm{C}$ for $60 \mathrm{sec}$. and $2 \mathrm{~min}$. in ice. Immediately after, $150 \mu \mathrm{L}$ of LB media containing ampicillin $\left(100 \mu \mathrm{g} \cdot \mathrm{mL}^{-1}\right)$, IPTG $(0.1 \mathrm{mM})$, and $\mathrm{X}$-Gal $\left(40 \mu \mathrm{g} \cdot \mathrm{mL}^{-1}\right)$ were added. White isolated colonies were selected for cloning confirmation by PCR reaction, using the same PCR conditions utilized in the amplification starting from the cDNA. For plasmidial DNA extraction from positive clones, the Kit NucleoSpin ${ }^{\mathrm{TM}}$ Plasmid (Promega, USA) was used, following the recommended instructions of the manufacturer.

Sequencing: genic sequencing of PCR products of the genes CAT1, PM25, SPS1, Transk and ABI5, was carried out in the Genomic Laboratory of the Instituto de Biotecnologia Aplicada à Agropecuária (Institute of Biotechnology Applied to Agriculture and Cattle Raising) of the Federal University of Viçosa, with the aid of a MEGABACE 1000 sequencing apparatus.

BLAST analyses and alignment: the sequences obtained from clones sequencing of genes CAT1, PM25, SPS1, Transk, and ABI5 were compared to sequences deposited on the international databank of the GenBank/ NCBI [National Center for Biotechnology Information (http://www.ncbi.nlm.nih.gov/BLAST/)], using the Blast $\mathrm{N}$ algorithm. The sequences obtained at NCBI that presented similarities with the nucleotide sequences of these genes when submitted to alignment using the CAP3 program (http://deepc2.psi.iastate.edu/aat/cap/cap.htm).

\section{Results and Discussion}

The radicle protrusion of the Melanoxylon brauna seeds removed from the original seed lot (control) started $72 \mathrm{~h}$ after imbibition. During the 96 to $132 \mathrm{~h}$ imbibition period, an increase in germination from $20 \%$ to $70 \%$ was observed, reaching 95\% after $168 \mathrm{~h}$ imbibition (Figure 1). The seeds that were subjected to drying at different periods of time and different temperatures presented gradual reduction on germination percent (Figure 1). The drying temperature, starting from $40{ }^{\circ} \mathrm{C}$ during $24 \mathrm{~h}$ (Figure 1A) was already sufficient to cause alterations on physiological quality of seeds. The increase on drying temperature accelerated the drying speed and consequently the loss of seeds quality. According to Carvalho and Nakagawa (2000) and Baker et al. (1991), the intensity of the immediate drying damages at more elevated temperatures varies with the plant species and depends on the interaction between the air drying temperature and initial moisture content of seeds, among other factors. For Berjak and Pammenter (2003), the two main causes for the loss on seeds viability by dehydration are the occurrence of imbalanced metabolism during dehydration and the damage caused by the dehydration, since water is essential for the intracellular structures integrity. 
$24 h$

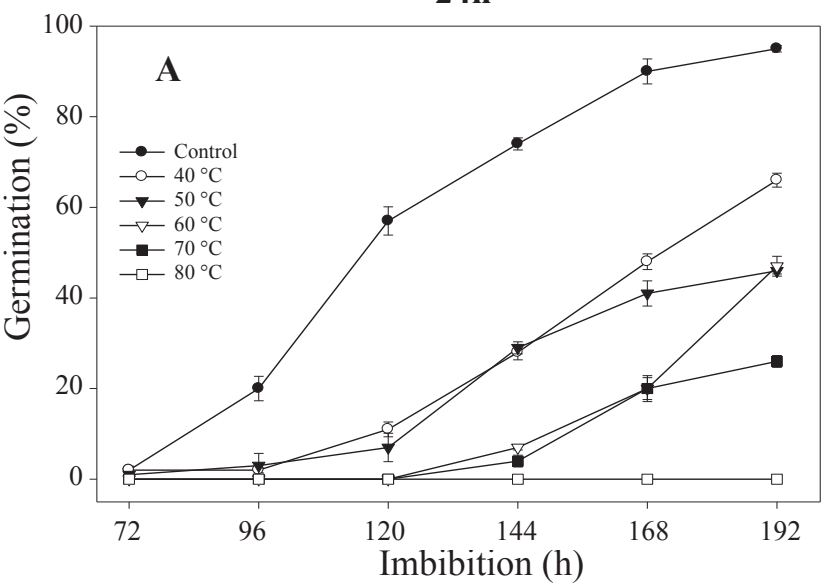

$48 h$

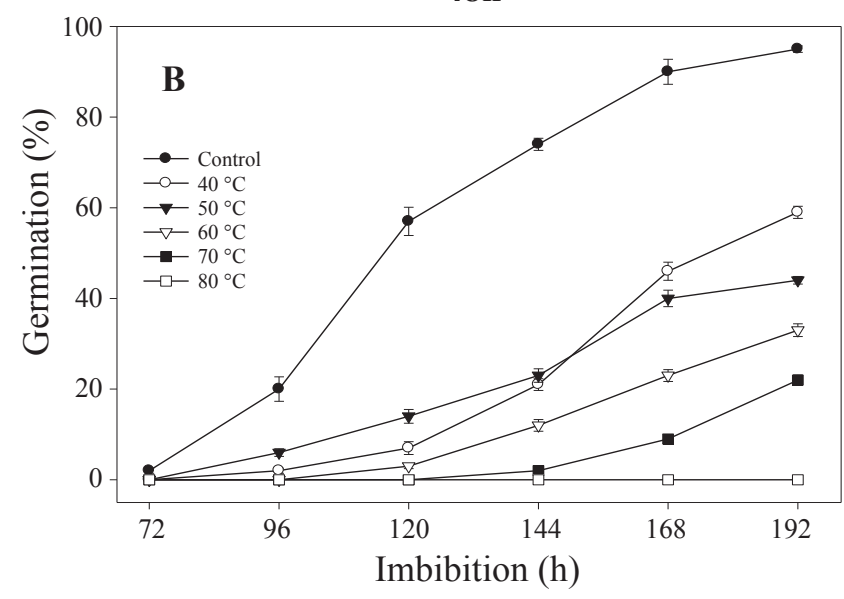

$72 \mathrm{~h}$

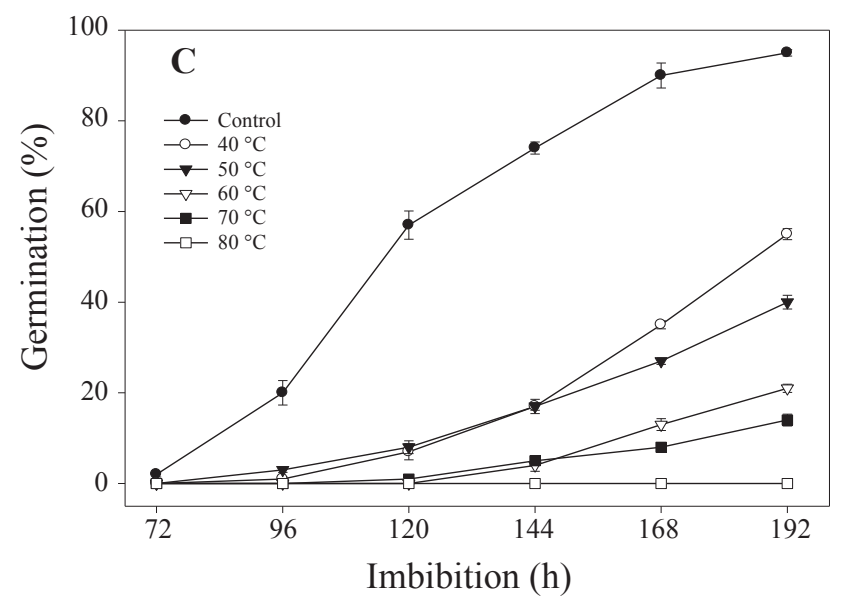

Figure 1. Germination of Melanoxylon brauna seeds submitted to oven drying for 24 (A), 48 (B) and 72 (C) hours, at temperatures of $40{ }^{\circ} \mathrm{C}, 50{ }^{\circ} \mathrm{C}$, $60{ }^{\circ} \mathrm{C}, 70{ }^{\circ} \mathrm{C}$ and $80{ }^{\circ} \mathrm{C}$; control: seeds dried at room temperature. The bar represents the standard deviation of mean.
Seeds have reduced moisture content after natural drying to accomplish total dehiscence (approximately 13\%). The water loss accompanied the increases on temperature and drying time (Figure 2) being faster at the first $24 \mathrm{~h}$ among all drying temperatures tested, predominantly at the higher temperatures.

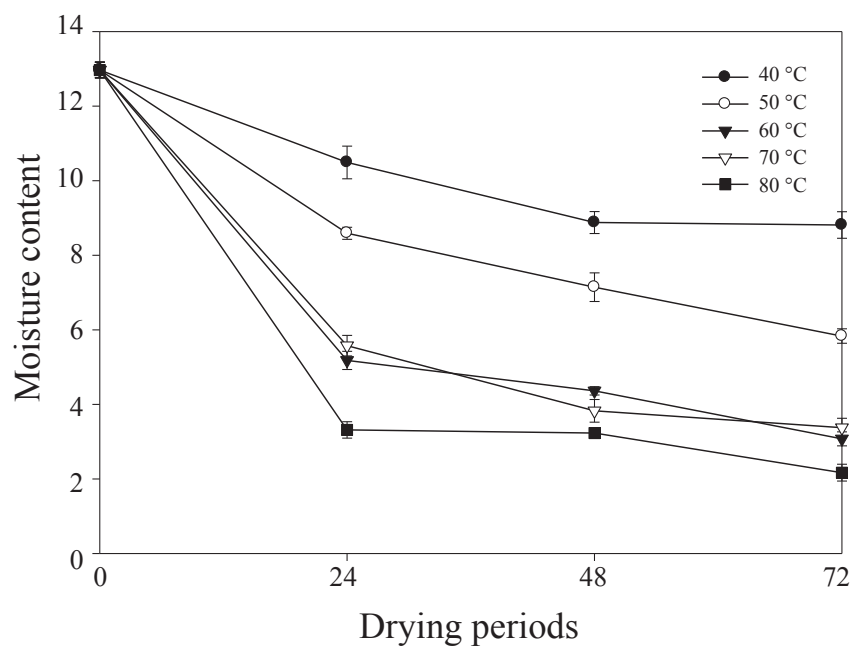

Figure 2. Changes in the moisture content (\%) of Melanoxylon brauna seeds submitted to oven drying for 24,48 and $72 \mathrm{~h}$ periods at temperatures of de $40^{\circ} \mathrm{C}, 50^{\circ} \mathrm{C}, 60^{\circ} \mathrm{C}$, $70{ }^{\circ} \mathrm{C}$ and $80^{\circ} \mathrm{C}$. Each point represents the mean of five replications of 20 seeds each. The bar represents the standard deviation of mean.

Reductions on moisture content to $10.5 \%$ and $7 \%$, respectively at the temperatures of $40{ }^{\circ} \mathrm{C}$ and $50{ }^{\circ} \mathrm{C}$, during the $24 \mathrm{~h}$ period, were already sufficient for diminishing seeds physiological characteristics. Those seed presenting moisture content below $6 \%$ after being submitted to drying, however, had final germination below $47 \%$. It is worth to emphasize that the moisture content of those seeds dried at temperatures of $60{ }^{\circ} \mathrm{C}$ and $70{ }^{\circ} \mathrm{C}$ (approximately $3.5 \%$ ) at the $72 \mathrm{~h}$ period was not sufficient for the total loss of seed viability. The drying at $80{ }^{\circ} \mathrm{C}$ caused seed death when the moisture content reached 2\% (Figure 3). Such tolerance to desiccation, inherent on Melanoxylon brauna seeds submitted to oven drying at the temperatures of $40{ }^{\circ} \mathrm{C}$, $50{ }^{\circ} \mathrm{C}, 60{ }^{\circ} \mathrm{C}$, and $70{ }^{\circ} \mathrm{C}$ cannot be attributed to a simple protection mechanism. On the contrary, it seems to be a multifactorial phenomenon in which each component is equally critic, synergistically acting, and controlled by the genome (Leprince et al., 1993). Evidences exist that 
the dehydration can cause the loss of cells capacity in synthesizing DNA, RNA, enzymes and proteins during rehydration (Leprince et al., 1990). Besides, the critic levels of moisture can affect the metabolic activity and cause damages in the tissues sensitive to dehydration (Vetucci and Ferrant, 1995; Walters et al., 2002a).

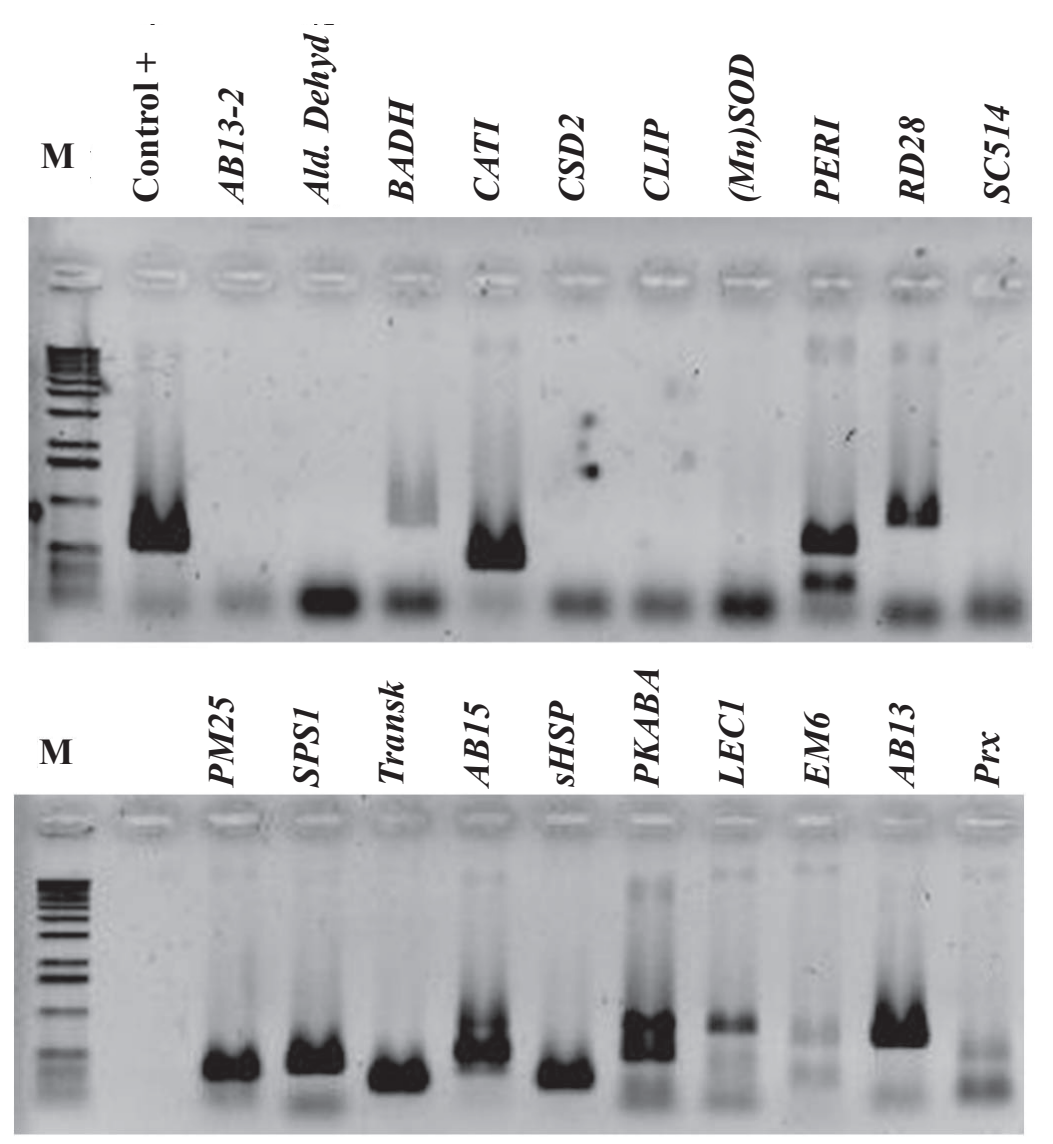

Figure 3. Electrophoresis analysis on 1\% agarose gel for the amplification capacity evaluation of degenerated oligosaccharides using DNA extracted from Arabidopsis thaliana leaves. M: 1kb Plus DNA Ladder; Control +: specific primer for Arabidopsis thaliana. At the upper part of the grooves are the acronyms of the genes used for primers formation.

The extraction of total RNA from embryonic axis of Melanoxylon brauna seeds by using the reagent Kit PureLink ${ }^{\mathrm{TM}}$ PlantRNA was efficient for obtaining RNA of good quality and suitable for later synthesis of cDNA.

From the 20 pairs of oligosaccharides tested with DNA extracted from Arabidopsis thaliana leaves, five containing the genes CAT1, SPS1, ABI5, Transk and $P M 25$ were selected for the amplification of homologous sequences, starting from Melanoxylon brauna cDNA. The choice of oligosaccharide pairs was based on the correspondence of size of the amplified fragment with the predicted size based on the Arabidopsis thaliana used for designing the oligosaccharides (Figure 3).

As can be observed on Figure 4, by means of PCR it was possible to verify the amplified products generated from the five pairs of selected primers and from Melanoxylon brauna cDNA. In relation to the products generated from that analysis it is possible to observe more than one fragment in the pairs of oligosaccharides evaluated.

After confirmation of the cloning of fragments obtained starting from the amplification using primers for the genes CAT1, SPS1, ABI5, Transk and PM25 and 
cDNA (Figure 5), the clones associated to the genes CAT1 (samples 1 and 5), SPS1 (samples 3, 4, and 5), $A B I 5$ (samples 8 and 9), Transk (sample 4) and PM25 (samples 4 and 5) were submitted to sequencing and presented amplified fragments of equal size to those obtained from cDNA amplification.

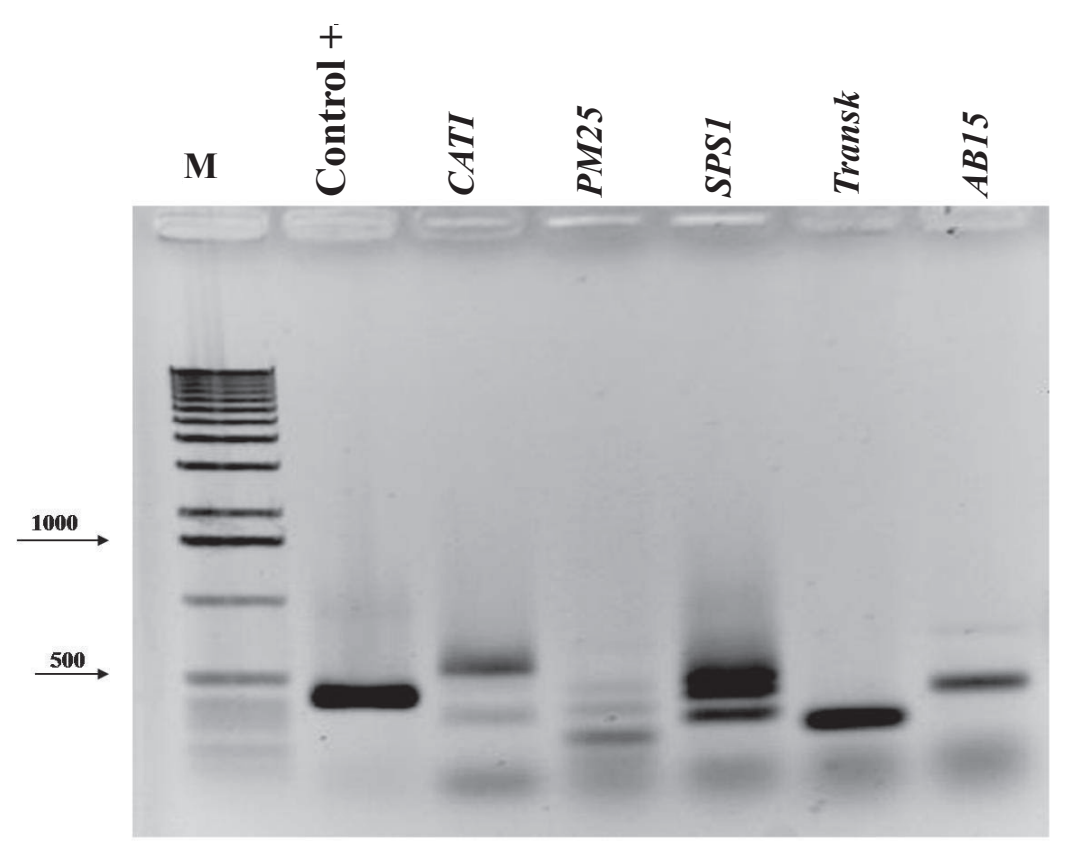

Figure 4. Electrophoretic analysis on 1\% agarose gel used for the amplification capacity validation of degenerated primers of Melanoxylon brauna cDNA. M: 1kb Plus DNA Ladder; Control +: Arabidopsis thaliana DNA and primers of $C A T 1$ gene. At the upper part of the grooves are the acronyms of the genes used for primers formation.

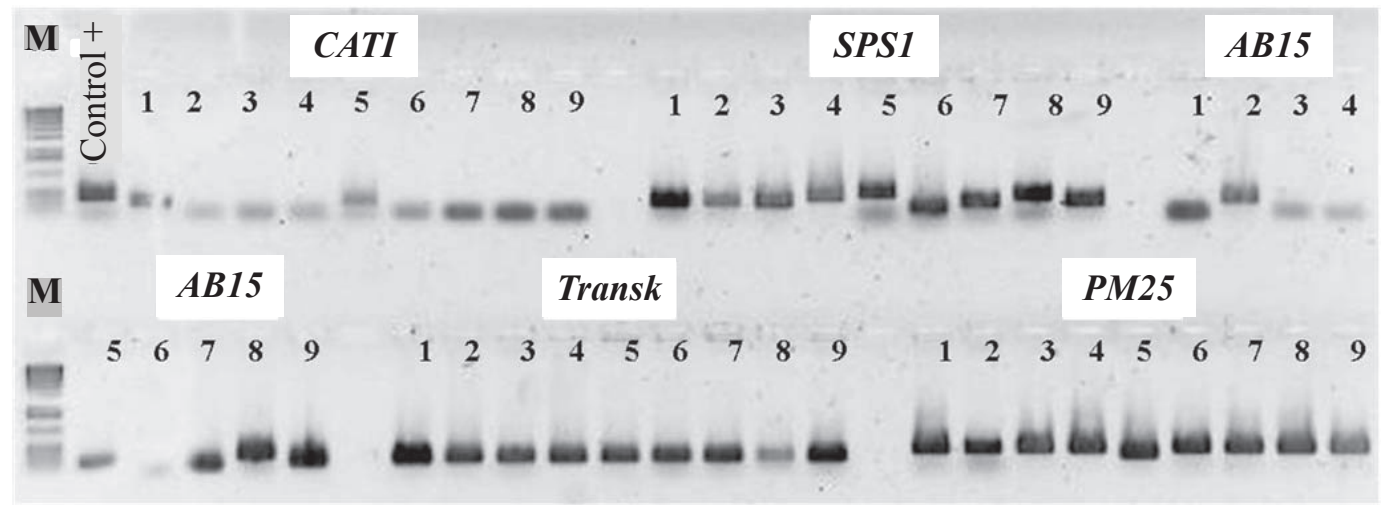

Figure 5. Electrophoresis analysis of PCR products of colonies used for cloning confirmation of fragments obtained starting from cDNA amplification of Melanoxylon brauna embryonic axis using degenerated oligosaccharide pairs designed from Arabidopsis thaliana gene sequences expressed in seeds and correlated to the development, maturation, protection, and tolerance to desiccation. M: $1 \mathrm{~kb}$ Plus DNA Ladder; Control +: Arabidopsis thaliana DNA and primers of CAT1 gene. In the grooves 1 to 9 are the transformed bacteria and primers of selected genes. At the upper part of the grooves are the acronyms of the genes used for primers formation. 
The similarity of the sequences obtained with the sequences of the homologous genes characterized in other plant species was verified, thus confirming the amplification and cloning of the gene and nucleotides sequences obtained from the sample 5, for the gene CAT1; for samples 3 and 5, for the gene SPS1; sample 4, for the gene Transk; and sample 8, for the gene PM25, used to produce the primers (Table 2).

Table 2. Analysis of similarity of cloned sequences corresponding to genes CAT1, SPS1, PM25 and Transk with sequences deposited in the NCBI (National Center for Biotechnology Information) data bank.

\begin{tabular}{clcccc}
\hline Genes & Species & Access number (NCBI) & size $(\mathrm{pb})$ & e-value & Identity $(\%)$ \\
\hline CAT1-5 & G. max & AF035252.1 & 1733 & 2e-110 & 88 \\
\hline \multirow{3}{*}{ SPS1-3 } & Medicago & AF322116.2 & 3579 & 2e-104 & 87 \\
& V. faba & Z56278.1 & 3419 & $8 \mathrm{e}-104$ & 87 \\
& H. lupulus & EF624248.1 & 963 & $3 \mathrm{e}-103$ & 87 \\
\hline \multirow{2}{*}{ SPS1-5 } & V. faba & Z56278.1 & 3419 & $1 \mathrm{e}-91$ & 88 \\
\hline \multirow{2}{*}{ PM25-8 } & A. thaliana & D64139.1 & 1080 & $8 \mathrm{e}-79$ & 100 \\
& A. thaliana & NM_113148.1 & 998 & $1 \mathrm{e}-44$ & 83 \\
\hline Transk-4 & G. max & AK244017.1 & 1224 & 9e-83 & 87 \\
\hline
\end{tabular}

Access number: identification of nucleotides sequences of some of the plant species deposited at the NCBI (National Center for Biotechnology Information) data bank - http://www.ncbi.nlm.nih.gov). Size: number of nucleotides; e-value: indicative of the probability of random occurrence of sequences alignment; identity: percent identity with the sequences deposited.

With the nucleotide sequences obtained from these genes, specific oligonucleotides pairs may be eventually designed for further studies of gene expression in order to correlate the expression of selected genes with the loss of germinative capacity of Melanoxylon brauna seeds.

\section{Conclusions}

"Brauna" (Melanoxylon brauna) seeds, when submitted to oven drying, show gradual reduction on the percent germination with the increasing temperature and drying time.

The genes CAT1, SPS1, ABI5, Transk, and PM25 of the braúna tree (Melanoxylon brauna) expressed in the embryonic axis of the seeds were partially characterized.

\section{Acknowledgements}

To the staff of Laboratory of Genomic from the Universidade Federal de Viçosa (UFV), Seed Laboratory of the UFV and Universidade Federal de Lavras (UFLA), for their aid in the laboratory tests; to $\mathrm{CNPq}$ for the scholarship granted; and to FAPEMIG for the financial support.

\section{References}

AALEN, R.B. Peroxiredoxin antioxidants in seed physiology. Seed Science Research, v.9, p.285-295, 1999.

AlAmillo, J.; ALMOGUERA, C.; BARTELS, D.; JORDANO, J. Constitutive expression of small heat shock proteins in vegetative tissues of the resurrection plant Craterostigma plantagineum. Plant Molecular Biology, v.29, p.1093-1099, 1995. http://www.springerlink.com/content/ v08268527614510p/fulltext.pdf

ANDERBERG, R.J.; WALKER-SIMMONS, M.K. Isolation of a wheat cDNA clone for an abscisic acid-inducible transcript with homology to protein kinases. Proceedings of the National Academy of Sciences, v.89, p.10183-10187, 1992. http://www.ncbi.nlm.nih.gov/pmc/articles/ PMC50302/pdf/pnas01095-0218.pdf

BAKER, K.D.; PAULSEN, M.R.; ZWEDEN, J.V. Hybrid and raying rate effects on seed corn viability. Transactions of the ASAE, v.34, n.2, p.499-506, 1991.

BERJAK, P.; PAMMENTER, N.W. Chapter 4: Orthodox and Recalcitrant Seeds. In: USDA Forest Service's/Reforestation, Nurseries; Genetics Resources. Tropical tree seed manual, 2003. p. 137-147.

BERNACCHIA, G.; SCHWALL, G.; LOTTSPEICH, F.; SALAMINI; BARTELS, D. The transketolase gene family of the resurrection plant Craterostigma plantagineum: differential expression during the rehydration phase. The EMBO Journal, v.14, n.3, p.610-618, 1995. http://www.ncbi. nlm.nih.gov/pmc/articles/PMC398120/pdf/emboj00027-0212.pdf 
BRASIL. Ministério da Agricultura, Pecuária e Abastecimento. Regras para análise de sementes. Ministério da Agricultura, Pecuária e Abastecimento. Secretaria de Defesa Agropecuária. Brasília: MAPA/ ACS, 2009. 395p.

CARVALHO, N.M.; NAKAGAWA. J. Sementes: ciência, tecnologia e produção. 4. ed. Jaboticabal, SP: Editora FUNEP, 2000.

COCA, M.; ALMOGUERA, C.; JORDANO, J. Expression of sunflower low molecular-weight heat-shock proteins during embryogenesis and persistence after germination: localization and possible functional implications. Plant Molecular Biology, v.25, p.479-492, 1994. http://www. springerlink.com/content/v4r65wu455t08696/fulltext.pdf

CROWE, J.H.; CROWE, L.M.; CHAPMAN, D. Infrared spectroscopic studies on interactions of water and carbohydrates with a biological membrane. Archives of Biochemistry and Biophysics, v.232, p.400-407, 1984.

DAVIDE, A.C.; CARVALHO, L.R.; CARVALHO, M.L.M.; GUIMARÂES, R.M. Classificação fisiológica de sementes de espécies florestais pertencentes à família Lauraceae quanto à capacidade de armazenamento. Cerne, v.9, n.1, p.29-35, 2003. http://redalyc.uaemex. $\mathrm{mx} / \mathrm{pdf} / 744 / 74409103 . \mathrm{pdf}$

DELSENY, M.; BIES-ETHEVE, N.; CARLES, C.; HULL, G.; VICIENT, C.; RAYNAL, M.; GRELLET, F.; ASPART, L. Late Embryogenesis Abundant (LEA) protein gene regulation during Arabidopsis seed maturation. Journal of Plant Physiology, v.158, p.419-427, 2001.

HARADA, J.J. Role of Arabidopsis leafy cotyledon genes in seed development. Journal of Physiology, v.158, p.405-409, 2001.

HUBER, S.C.; HUBER, J.L. Role and regulation of sucrose-phosphate synthase in higher plants. Annual Review of Plant Physiology and Plant Molecular Biology, v.47, p.431-444, 1996.

IBAMA - Instituto Brasileiro do Meio Ambiente e dos Recursos Naturais Renováveis. Lista Oficial de Flora Ameaçada de extinção. Portaria $n^{\circ}$. 37-N, de 3 de abril de 1992. http://www.ibama.gov.br/patrimonio. Acesso em: 4 abr. 2009.

JONES, H.D.; PETERS, N.C.; HOLDS WORTH, M.J. Genotype and environment interact to control dormancy and differential expression of the viviparous 1 homologue in embryos of Avena fatua. The Plant Journal, v.12, n.4, p.911-920, 1997.

KOSTER, K.L.; LEOPOLD, A.C. Sugars and desiccation tolerance in seeds. Plant Physiology, v.88, n.3, p.829-832, 1988. http://www.ncbi. nlm.nih.gov/pmc/articles/PMC1055669/pdf/plntphys00633-0329.pdf

KOORNNEEF, M.; REULING, G.; KARSSEN, C. M. The isolation and characterization of abscisic acid-insensitive mutants of Arabidopsis thaliana. Physiologia Plantarum, v.61, p.377-383, 1984.

LEPRINCE, O.; HENDRY, G.A.F.; MCKERSIE, B.D. The mechanisms of desiccation tolerance in developing seeds. Seed Science Research, v.3, p.231-246, 1993.
LEPRINCE, O.; DELTOUR, R.; THORPE, P.C.; ATHERTON, N. W.; HENDRY, G.A.F. The role of free radicals and radical processing systems in loss of desiccation tolerance in germinating maize (Zea mays L.). New Phytologist, v.116, p.573-580, 1990. http://onlinelibrary.wiley. com/doi/10.1111/j.1469-8137.1990.tb00541.x/pdf

LEPRINCE, O.; HARREN, F.J.M.; BUITINK, J.; ALBERBA, M.; HOEKSTRA, F.A. Metabolic dysfunction and unabated respiration precede the loss of membrane integrity during dehydration of germinating radicles. Plant Physiology, v.122, n.2, p.597-608, 2000. http://www. plantphysiol.org/content/122/2/597.full.pdf + html

ORENDI, G.; ZIMMERMANN, P.; BAAR, C.; ZENTGRAF, U. Loss of stress-induced expression of catalase 3 during leaf senescence in Arabidopsis thaliana is restricted to oxidative stress. Plant Science, v.161, p.301-314, 2001.

PARCY, F.; VALON, C.; RAYNAL, M.; GAUBIER-COMELLA, P.; DELSENY, M.; GIRAUDAT, J. Regulation of gene expression programs during Arabidopsis seed development: roles of the ABI3 locus and of endogenous abscisic acid. The Plant Cell, v.6, p.1567-1582, 1994. http:// www.plantcell.org/content/6/11/1567.full.pdf + html

PUKACKA, S.; RATAJCZAK, E. Production and scavenging of reactive oxygen species in Fagus sylvatica seeds during storage at varied temperature and humidity. Journal of Plant Physiology, v.162, n.8, p.873-885, 2005.

RACKER, A. In: BOYER, P.; LARDY, H.; MYRBACK, K. (Eds.). The Enzymes. New York: Academic Press, 1961. v.5, p. 397-406.

VERSLUES, P.E.; BATELLI, G.; GRILlO, S.; AGIUS, F.; KIM, Y.; ZHU, J.; ZHU, J.; AGARWAL, M.; KATIYAR-AGARWAL, S.; ZHU, J. Interaction of SOS2 with NDPK2 and catalases reveals a point of connection between salt stress and $\mathrm{H}_{2} \mathrm{O}_{2}$ signaling in Arabidopsis. Molecular Cell Biology, v.27, p.7771-7780, 2007. http://mcb.asm.org/ content/early/2007/09/04/MCB.00429-07.short

VERTUCCI, C.W.; FARRANT, J.M. Acquisition and loss of desiccation tolerance. In: KIEGEL, J.; GALILI, G. (Eds.). Seed development and germination. New York: Marcel Dekker, 1995. p. 237-271.

VILLELA, F.A.; PERES, W.B. Coleta, beneficiamento e a armazenamento. In: FERREIRA, A. G.; BORGHETTI, F. Germinação do básico ao aplicado. Porto Alegre: Artmed, 2004.

WALTERS, C.T.; TOUCHELL, D.H.; POWER, P.; WESLEY, S.J.; ANTOLIN, M.F. Desiccation stress and damage. In: BLACK, M.; PRITCHARD, H.W. (Eds.). Desiccation and survival in plants. Wallingford: CABI, 2002a. p. 263-282.

WALTERS, C.T.; TOUCHELL, D.H.; POWER, P.; WESLEY, S.J.; ANTOLIN, M.F.A Cryopreservation protocol for embryos of the end angered species Zizania texana. Cryo Letters, v.23, n.5, p.291-298, 2002 b.

WATERS, E.; LEE, G.; VIERLING, E. Evolution, structure and function of the small heat shock proteins in plants. Journal of Experimental Botany, v.47, p.325-338, 1996. http://jxb.oxfordjournals.org/content/47/3/325.full.pdf + html 
WEHMEYER, N.; VIERLING, E. The expression of small heat shock proteins in seeds responds to discrete developmental signals and suggests a general protective role in desiccation tolerance. Plant Physiology, v.122, p.1099-1108, 2000. http://www.plantphysiol.org/content/122/4/1099.full.pdf+html

WILLIAMSON, J.D.; SCANDALIOS, J.G. Differential response of Maize catalases to abscisic acid: Vp1 transcriptional activator is not required for abscisic acid-regulated cat 1 expression. In: NATIONAL ACADEMY OF SCIENCES, 1992, USA. Proccedings... USA, 1992. v. 89, p.8842-8846. http://www.ncbi.nlm.nih.gov/pmc/articles/PMC50017/?page=1
XING, Y.; JIA, W.; ZHANG, J. AtMEK1 mediates stress-induced gene expression of CAT1 catalase by triggering $\mathrm{H}_{2} \mathrm{O}_{2}$ production in Arabidopsis. Journal of Experimental Botany, p.1-13, 2007. http://jxb. oxfordjournals.org/content/58/11/2969.full.pdf + html 